THE HISTORY OF THE BRITISH FLORA. H. Godwin. Cambridge, The University Press, I956. 384 pages, I I 9 text-figures, 26 pages of plates, $28.5 \mathrm{~cm}$. Price $£ 4$ ros. od.

ThIs monumental work by Dr. Godwin falls into three distinct parts, the central one being "The Plant record". This, the largest section, p. 69 to p. 292, is a catalogue of all the plants which have been recorded in deposits from the beginning of the Ice Age up to historic times. The catalogue is in great detail and not only gives the references to the records but comments on their significance, usually giving the present distribution of the plant.

This is the factual evidence on which his thesis is based. For others who are not botanists but who are interested in what the plants tell of climate and climatic changes during the Ice Age and Post-glacial time, the chapter on "The background scale of Quaternary change", Chapter III, gives a full summary of the stratigraphy and results which have emerged from the recent studies of interglacial and Post-glacial deposits, largely based on the technique of pollen analysis.

Correlation tables, such as Fig. 29, p. 62, show in a comprehensive way the details of late glacial and Post-glacial time, that is, for the last 12,000 years. In this table vegetation type, archaeology, geology and climate are all shown in a way which makes the correlation of these various items easy to follow.

To many interested mainly in glaciology and in the way the effects of ice cover and climatic change are recorded by the plants, Chapter VI "Pattern of change in the British Flora" p. 293-349 will be of great interest; naturally the evidence so far obtained for the interglacial and glacial periods is small compared with that of late glacial and Post-glacial times but Dr. Godwin states (p. 303) "The more we learn of the interglacial floras the more similar they seem to be to one another, and indeed the less they differ from our Post-glacial flora". However, he also notes that each interglacial flora does show differences from the Post-glacial and other interglacial floras which enable it to be identified on its flora.

Chapter VII "Conclusion" is short, only 6 pages-but these give a summary of the whole thesis in a masterly way and emphasize the importance of the detailed work which has been necessary to arrive at a proper appreciation of the history of our flora and the lessons which it can teach. Dr. Godwin contends that he has been able to show that much of our flora was present in Britain while ice fields occupied the northern parts of the country, and that before the North Sea filled up again practically the whole of the present flora which had not "wintered" here had been able to migrate in from the continent.

The "Plant record" is a most valuable reference book but the other chapters, particularly the last two, make fascinating reading as Dr. Godwin develops his thesis to its natural conclusion.

W. B. R. KING

\title{
CORRESPONDEN CE
}

The Editor,

The Fournal of Glaciology SIR,

The Mechanical Measurement of Glacier Motion

In his article on this subject (fournal of Glaciology, Vol. 2, No. 19, 1956, p. 642) Mr. Galloway speaks of measurements of the movement of Lyngsdalsbreen with a new instrument which one can class in the general category of Gletscheruhr; he also cites earlier experiments in this direction. These investigations should meet with great general interest since we know far too little about the actual course of glacier movement, particularly over very short periods of time. At the same time it seems that Mr. Galloway is not aware of the fact that I have also carried out measurements in Norwegian glaciers, particularly in Nigardsbreen (Jostedalsbreen), with an instrument which I designed expressly for the purpose, and I would therefore like to draw attention to this work. (See references below.)

The Cryocinegraph which I developed was erected on a glacier tongue after laboratory tests, and was in operation there for several weeks, the results being to some extent surprising; I published these results in due course. (See below.) According to my experience of the results obtained with 